\title{
Students' perception towards modern technology as teaching Aids
}

\author{
Raja Nazim Abdullah ${ }^{1}$, Junaidah Abdul Muait ${ }^{2}$, Ganefri $^{3}$ \\ ${ }^{1}$ Faculty of Technical and Education, Sultan Idris Education University, \\ 35900 Tanjong Malim, Perak, Malaysia \\ ${ }^{2}$ School of Educational and Social Sciences, Management and Science University, \\ 40100 Shah Alam, Selangor, Malaysia \\ ${ }^{3}$ Faculty of Engineering, Universitas Negeri Padang, J1. Prof. Dr. Hamka, Air Tawar Bar., Kec. Padang \\ Utara, Kota Padang, Sumatera Barat 25132, Indonesia. \\ rajanazim@ftv.upsi.edu.my ${ }^{1}$
}

Received: 1 December 2019; Accepted: 15 December 2019; Published: 21 December 2019

\begin{abstract}
Education is any combined of learning experiences designed to help learners with the opportunity exploration of knowledge. This paper aims to highlight the substance of considering students' perceptions of modern approach teaching and learning process. To accomplish this objective, researchers identified 45 subjects relevant to the research objective of the recent study. The result indicates that student's perceptions regarding teaching aids using modern technology are significant, consider modern education as a viable option to an effective education. The findings of the study provide grasp of perspective into the administration of higher learning institutions regarding the aspect that lead to the satisfaction as university students.
\end{abstract}

Keywords: Education, Perception, Technology, Teaching Aids

\section{INTRODUCTION}

The era of globalization show the growth of various advanced technologies around the world. Web 2.0 technologies are one of the most essential technologies and tools or applications enable learners to create, generate, and contribute knowledge in a form of information sharing exploration, and ideas collaboratively with not only other learners or instructors, but also with others around the globe who have similar interests (Sumuer, 2018). The World Wide Web (WWW) was made to link information to the people, who is the users using Internet. The Internet is the technology of networks to connect people around the world. The network can be transformation of data using devices such as personal computer, mainframe, supercomputer, and mobile device (tablets/smartphones).

There are many different models, designs and functions of mobile device available on the market today. The most popular mobile devices are tablets and smart phone. Smart phone has multi functions for the users to make them ease for their daily routine activities like make and receive phone calls or texts messaging, take photos and record videos, browse the Internet, listen to music or watch video clip, and read news. The two popular smart phones platforms are Android and iOS and there are more than million apps available with wide range of apps categories such as games, business, educational, entertainment, and lifestyle.

Higher learning education is gradually being recognized as a service industry, where the students are the customer. Service providers are beginning to comprehend that product or service alone cannot retain their customers but to have clearer understanding of customer's impression of quality provided. Hence, higher learning institution must keep in view of student's insight concerning the process of teaching and learning in classroom. It was found that previous research done on student perception related to teaching and learning mostly focused on education in general.

The focus of this study is therefore placed on the perception of teaching and learning delivered by educators at a higher learning institution. This study focused on two research questions. The following research questions were set:

RQ1: How technology used in classroom effect student's satisfaction?

RQ2: Are student experience in learning influence by different approach in teaching and learning? 


\section{STUDENT PERCEPTION}

Based on the definition from Oxford learners dictionaries (2019), perception can be defined as the "the way you notice things, especially with the senses, the ability to understand the true nature of something, and an idea, a belief or an image you have as a result of how you see or understand something".

There is an extensive literature studying the determinants of student perception. According to Lizzio, Wilson and Simons (2002) there are evidence in past literatures indicate that there are clear relationships between students' perceptions, approaches and outcomes. Student expectation can be deliberated by explaining three main categories that are course contents, experiential, and outcomes. To response those expectation, the seemly question is does the type of academic environment within student learning location have any impact on how they approach their learning and the quality of the outcomes they are able to achieve? (Lizzio et al.,2002). The best outcomes students attain are that they are taught rather than by what they learn in school or higher institution. Tangible and intangible factors have a significant effect on student perception. Factors related to levels of satisfaction and students' perceptions of quality will attract them in many directions.

Nell and Cant (2014) cited a study from Voss et al. (2007) that the reason why it is important for higher learning institution to understand students perception is, it enable the students to be in an better position in order to handle their perceptions. Students who have a positive experience with these administrative departments may be more satisfied, which can further result in spreading positive word of mouth, creating loyalty among current students and attracting potential students, which may ultimately lead to students enrolling for more additional courses (Nell and Cant, 2014).

There is significant research evidence state that teaching and learning environments are very much influential on student satisfaction and overall achievement. Knowledge delivery is important to students, but approach of deliver by educator to student can be much more influential in students' satisfaction in school and higher education. Engagement between educator and students and discussions regarding student perception of their learning contexts can grant crucial insight into student overall behavioral.

Understanding students' perceptions is relatively important to determine what they wants as different generation show different categories of acceptance. According to Abdullah et al. (2018) The status quo of present higher learning institution scenario are, the educators are those among the Baby Boomers and Gen-Xers are the one who teach Gen-Y and Gen-Z students. It was found that students expressed a need for interactive lectures seemed to favor in combination of technology in teaching aids.

Flexible teaching and learning such as blended learning, flipped classroom, massive open online courses (MOOC), and distance learning have become key terms reflecting innovative pedagogies in school and higher education (Wanner and Palmer, 2015). Hence, educator who practices variety of teaching approaches that comprise assortment of modern delivery medium may lead to higher student engagement. A number of students also favored to have all needed materials available via online or offline for simplify cross reference information collected.

This study focuses on student demographic profile and ICT, and their impact on perception about implementation of technology by educators. Therefore, this study identifies and measure the extent to which students' characteristics influence higher education quality so that university authorities and policy-makers can segment the entire student pool into subgroups based on the differences of students' characteristics and target the right group of students.

Students wanted learning opportunities that enable them to improve experience. As an educator, the use mobility or mobile technology to promote learning is vital, also important to examine strategies of both mobile learning and collaborative learning, and the best ways if to blend the two to create effective learning experiences for students (Heflin, Shewmaker and Nguyen, 2017). This will result to an outcomes that constitute students' success with higher rate. Student nowadays expected a conducive learning environment from educational service provider. Most of school and higher learning institution administered using range of technology as a replacement for typical face-to-face class to modern types of pedagogical. 


\section{MODERN TECHNOLOGY AS TEACHING AIDS}

Modern technology is so called an advancement of information and communications technology (ICT) and ICT-related products are available and assessable around us as consumers. Computers and mobile devices have become tools for communication, businesses and work. Modern technology in education has potential to revolutionize inclusive educational system in the aim of increasing economic productivity through socio-economic goals in various sectors. These technologies offer the opportunity to embed learning in a natural environment and also deliver sensational effects and has extended the traditional learning paradigm into a new phenomenon, it is called mobile learning (m-learning) ( $\mathrm{Su}$ and Cheng, 2015).

Digital literacy has coming to the intention of educators to be able to arrange knowledge delivery across fields with adaption of technology and media. Digital literacy is the ability to participate in a range of critical and creative practices with different types of technology and media. Educators should steer clear of the business as usual especially in teaching and learning process. There are lots of module that integrate with the use of technology available in Internet to practice in classroom. Chalk and talk method is no longer effective specifically to young generation students. These students need to be able to participate in numerous of creative activities involving technology. New generation of students are keen to intensify their motivation, which is an important aspect of learning and with student engagement, will encourage them to solve real situation problems.

Modern educational theory stresses learning as a learner-centered activity (Su et al., 2015) and ideas with the help of technology enables educator to enter into collaborative digital practices. Blended learning initiatives are rising due to advances in technology around the world and these initiatives are now seen as playing an increasingly more prominent role to students assimilate information and learn within an educational setting (Moraros, Islam, Yu, Banow and Schindelka, 2015). According to Osman et al. (2019), innovative culture for an organization with the leader who has clear vision, high determination on work or task, and concerned for future direction. Thus, this culture should apply not only organizations in industry but also to be practiced in education sector.

\section{METHODOLOGY}

This paper designs and implements a small scale experiment in the classroom which the study was conducted an experimental research to gain insights on the effect of technology used in classroom and student perception. To further understand the point of view from respondents, probed questionnaire was designed. The study consisted of the initial session which students were experience the modern technology in teaching and learning process, and then, the distribution of questionnaire to respondents. The survey asked respondents with open-ended questions about their opinions toward the activity in the experiment session.

The questionnaire was divided into two parts with closed-ended questions typed. The first part was questions regarding student demographic profile and second part focus on student experience and student perception, which address independent variable and dependent variable. The construct of questionnaire was map into a development series of questions about students' experiences and perceptions of learning institution and issues affecting their satisfaction in education.

In this experiment, groups of 45 students in selected classroom were invited to participate whereby a stratified random sampling was used. Similar to typical teaching and learning process, researcher as an instructor started to brief respondents the flow of the activity. The session of the test exploratory investigation was kept around 5 minutes for every respondent which they were divided into consecutive areas for adapting course substance and virtual reality (VR) experience. The respondent wore VR gear set and implemented the module given by the instructor. The module performed by turn for each of respondent until the last respondent completed. Next session, instructor distribute questionnaire probed with demographic profile and experience learning measure. 


\section{RESULT}

Data were analyzed in two phases. In the first phase, descriptive analysis was used to describe the frequency and percentage extract from the data. In the second phase, researchers went through multivariate analysis where the dependent variable was modeled as a joint effect of all the independent variables. All data were analyzed using the SPSS (version 26.0) statistical program.

The main goal in this study was to measure how students perception toward different teaching and learning approach. The first part describes respondent demographics profile (gender, age, race, stage of studies, residence location) (Table 1). Then, next part report student perception towards the use of technology by the educators with the progressive change in higher education approaches.

In total, there were 45 respondents with 80 percent are female, 15 respondents ages between 20 23 and 30 of them ages between 24-29. The data collected shown all the respondents own smart phone, almost 90 percent own laptop, 2 respondents have their own personal computer and only 1 owns tablet. To understand data further, respondents were asked their learning experience on the implementation of the use of technology in teaching and learning.

Table 1. Demographic Profile Gender

\begin{tabular}{|c|c|c|}
\hline & Frequency & Percent \\
\hline Male & 9 & 20.0 \\
\hline Female & 36 & 80.0 \\
\hline Total & 45 & 100.0 \\
\hline \multicolumn{3}{|c|}{ Age } \\
\hline $20-23$ & 15 & 48.9 \\
\hline $24-29$ & 30 & 51.1 \\
\hline Total & 45 & 100 \\
\hline \multicolumn{3}{|c|}{ Race } \\
\hline Malay & 44 & 97.8 \\
\hline Chinese & 1 & 2.2 \\
\hline Total & 45 & 100 \\
\hline \multicolumn{3}{|c|}{ Stage of studies } \\
\hline Second year & 3 & 6.7 \\
\hline Third year & 42 & 93.3 \\
\hline Total & 45 & 100 \\
\hline \multicolumn{3}{|c|}{ Residence location } \\
\hline Kuala Lumpur & 1 & 2.2 \\
\hline Selangor & 1 & 2.2 \\
\hline Perak & 14 & 31.1 \\
\hline Penang & 1 & 2.2 \\
\hline Kedah & 4 & 8.9 \\
\hline Negeri Sembilan & 2 & 4.4 \\
\hline Melaka & 2 & 4.4 \\
\hline Johor & 3 & 6.7 \\
\hline Pahang & 1 & 2.2 \\
\hline Terengganu & 4 & 8.9 \\
\hline Kelantan & 5 & 11.1 \\
\hline Sabah & 5 & 11.1 \\
\hline Sarawak & 2 & 4.4 \\
\hline Total & 45 & 100 \\
\hline
\end{tabular}


Table 2. Mean Analysis

\begin{tabular}{clccc}
\hline No. & \multicolumn{1}{c}{ Item } & N & Mean & $\begin{array}{c}\text { Std. } \\
\text { Deviation }\end{array}$ \\
\hline 1. & I often use laptop/computer in my classroom. & 45 & 3.022 & 1.076 \\
2. $\quad \begin{array}{l}\text { I used a laptop/computer to prepare assignments or reports. } \\
\text { I utilized online learning materials provide by educators } \\
\text { 3. }\end{array}$ & 45 & 4.844 & 0.520 \\
$\quad \begin{array}{l}\text { (course outlines, syllabus, notes, presentations, etc.) } \\
\text { I participated in class discussion using online or electronic } \\
\text { medium (chat group, forum) }\end{array}$ & 45 & 4.444 & 0.724 \\
5. I used computer to produce visual displays of information & 45.733 & 0.809 \\
\hline & \multicolumn{1}{c}{ Total } & 45 & 4.311 & 0.733 \\
\hline
\end{tabular}

Researchers further explore the students trends with occasionally use either laptop or computer during the learning process. This situation occurred due to the less used of technological assistant as teaching aids from the educators. On the other hand, most of the students clarify that they were using laptop and computer to prepare assignments or reports since that technology is dramatically improving and help students to search information from any resources available either primary information or secondary information. Furthermore, digital devices such as laptop and personal computer create opportunity for student to conduct research, take notes and write report. These devices allow student to easily access to the Internet to have clear and updated information on any topics. Past literatures prove the usefulness and helpfulness of digital devices can positively affect student performance particularly in academic. In addition, taking notes on laptop is overall easier to write and to add information as well as to edit written topic.

\section{CONCLUSION}

It has become mutual that the use of technology in classroom can support and be supported by different types of pedagogy that allow learner to understand, sensation, and appreciate. Students have positive perceptions of modern education, hence, higher learning institution should provide facilities and teaching equipment to upsurge quality enhancement of student learning engagement. The impact from the study is aims to transform the nation's higher learning education to produce excellent human capital with an outstanding mentality. As indicate in the result, the use of technology as part of teaching tools will influence student motivation for the enhancement of student's overall learning experience. It is important for educational institutions to vigorously monitor the quality of the services they offer to continuously make improvements in order to survive in local and global competitive environment. 


\section{REFERENCES}

Abdullah, R. N., Azman, M. N. A., Kamal, M. F. M., Riu, T. J., \& Yaacob, R. A. I. R. (2018). Experiential Learning: The Effective Application of Virtual Reality in Teaching and Learning. The Journal of Social Sciences Research, 1208-1212.

Heflin, H., Shewmaker, J., \& Nguyen, J. (2017). Impact of mobile technology on student attitudes, engagement, and learning. Computers \& Education, 107, 91-99.

Lizzio, A., Wilson, K., \& Simons, R. (2002). University students' perceptions of the learning environment and academic outcomes: implications for theory and practice. Studies in Higher education, 27(1), 27-52.

Moraros, J., Islam, A., Yu, S., Banow, R., \& Schindelka, B. (2015). Flipping for success: evaluating the effectiveness of a novel teaching approach in a graduate level setting. BMC medical education, 15(1), 27.

Nell, C. E., \& Cant, M. C. (2014). Determining student perceptions regarding the most important service features and overall satisfaction with the service quality of a higher education institution. Management: journal of contemporary management issues, 19(2), 63-87.

Osman, N.W., Kamis, A. (2019). Innovation Leadership for Sustainable Organizational Climate in Institution of Technical and Vocational Education and Training (TVET) in Malaysia. Asian Journal of Assessment in Teaching and Learning, 9 (1), 57-64.

$\begin{array}{lllll}\text { Oxford } & \text { Dictionaries. } & \text { Perception. } & \text { Retrieved }\end{array}$ https://www.oxfordlearnersdictionaries.com/definition/english/perception

Voss, R., Gruber, T. \& Szmigin, I. (2007). Service quality in higher education: The role of student expectations. Journal of Business Research, 60(9), 949-959.

$\mathrm{Su}$, C. H., \& Cheng, C. H. (2015). A mobile gamification learning system for improving the learning motivation and achievements. Journal of Computer Assisted Learning, 31(3), 268-286.

Sumuer, E. (2018). Factors related to college students' self-directed learning with technology. Australasian Journal of Educational Technology, 34(4).

Wanner, T., \& Palmer, E. (2015). Personalising learning: Exploring student and teacher perceptions about flexible learning and assessment in a flipped university course. Computers \& Education, 88, 354-369. 